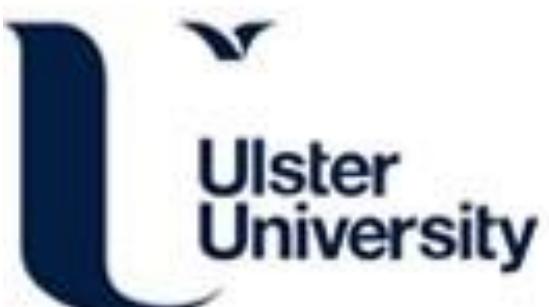

\section{Social dimensions of science-humanitarian collaboration: lessons from Padang, Sumatra, Indonesia}

Shannon, R., Hope, M., McCloskey, J., Crowley, D., \& Crichton, P. (2014). Social dimensions of science-humanitarian collaboration: lessons from Padang, Sumatra, Indonesia. Disasters, 38(3), 636-653.

Link to publication record in Ulster University Research Portal

Published in:

Disasters

Publication Status:

Published (in print/issue): 01/07/2014

\section{Document Version}

Publisher's PDF, also known as Version of record

\section{General rights}

Copyright for the publications made accessible via Ulster University's Research Portal is retained by the author(s) and / or other copyright owners and it is a condition of accessing these publications that users recognise and abide by the legal requirements associated with these rights.

\section{Take down policy}

The Research Portal is Ulster University's institutional repository that provides access to Ulster's research outputs. Every effort has been made to ensure that content in the Research Portal does not infringe any person's rights, or applicable UK laws. If you discover content in the Research Portal that you believe breaches copyright or violates any law, please contact pure-support@ulster.ac.uk. 


\title{
Social dimensions of science-humanitarian collaboration: lessons from Padang, Sumatra, Indonesia
}

\author{
Rachel Shannon, Max Hope, John McCloskey, Dominic Crowley, and \\ Peter Crichton ${ }^{1}$
}

This paper contains a critical exploration of the social dimensions of the science-humanitarian relationship. Drawing on literature on the social role of science and on the social dimensions of humanitarian practice, it analyses a science-humanitarian partnership for disaster risk reduction $(D R R)$ in Padang, Sumatra, Indonesia, an area threatened by tsunamigenic earthquakes. The paper draws on findings from case study research that was conducted between 2010 and 2011. The case study illustrates the social processes that enabled and hindered collaboration between the two spheres, including the informal partnership of local people and scientists that led to the co-production of earthquake and tsunami DRR and limited organisational capacity and support in relation to knowledge exchange. The paper reflects on the implications of these findings for science-humanitarian partnering in general, and it assesses the value of using a social dimensions approach to understand scientific and humanitarian dialogue.

Keywords: case study approach, disaster risk reduction, geoscience, partnership, social dimensions, Sumatra

\section{Introduction}

Scientific research can make an important contribution to humanitarian policy development and programme delivery, and the need to strengthen dialogue between the humanitarian and the scientific communities is well recognised (HFP, 2007; Wilby, 20I0). However, there are a number of barriers to effective knowledge exchange, including: the limited capacity of the humanitarian sector to understand and use scientific research, and of the research community to perceive and respond to user needs; funding mechanisms and reward structures that do not fully support collaboration; differences in organisational structure and working practices; and the limited 'purchase' natural science solutions have on the long-term socio-political issues that cause many humanitarian crises (HFP, 2007; Budds, 2009).

Barriers of this sort are examples of the social dimensions that underpin both scientific and humanitarian practice, and more effective science-humanitarian partnering will be enabled if they are comprehended better (Anderson, I999; Forsyth, 2003). A recent special edition of Disasters examined how these issues pertain to humanitarian activities (Hilhorst, Dijkzeul, and Herman, 20IO) and there is a large social study of science literature that considers similar themes with respect to the social role of science (Gergen, I985; Yearley, 2005; Wynne, 2006). To date, though, few studies have examined specifically the social dynamics of the science-humanitarian relationship. 
This paper addresses this gap by identifying the key social dimensions of scientific and humanitarian practice. It develops these points by considering the findings of case study research conducted in 2010 and 2OII. This research examined a sciencehumanitarian partnership for disaster risk reduction (DRR) in Padang, Sumatra, Indonesia, and the analysis reveals how DRR programmes were co-produced through complex interaction between scientists, humanitarians, and the local community, with personal values and motivations playing an important role. It pinpoints differences between science and humanitarian working practices, the strengths and weaknesses of informal organisational structures, and issues of institutional capacity and the funding of knowledge exchange activities. The paper concludes by drawing out the implications of this case study for the science-humanitarian relationship in general.

\section{Social dimensions of humanitarian practice}

Humanitarian agencies traditionally have followed the humanitarian imperative and delivered aid to people in conflict and disaster settings in impartial and non-partisan ways (Stockton, I998). Yet, as Pelling and Dill (20I0) have observed, humanitarian agencies are increasingly likely to acknowledge the socio-political dimensions of their work and to align themselves with a politically engaged developmental perspective. While this may be so, the socio-political dimensions of humanitarian action can still go unrecognised in ways that hinder the effective achievement of humanitarian goals (Anderson, I999; Kennedy, 2008). For example, humanitarian interventions are conducted by groups and organisations with their own priorities, values, and ways of working, and these can interact in unintended ways with local structures to hinder humanitarian actions (Handler Chayes, Chayes, and Raach, I997; Weiss and Hoffman, 2007; Clarke and Ramalingham, 2008). Anderson (I999) draws attention to the implicit ethical messages of humanitarian activities and how disrespect and competition between aid agencies and a preoccupation with the personal safety of aid workers can undermine local trust in the legitimacy and the authority of aid organisations.

Hilhorst, Dijkzeul, and Herman (20IO) have looked in detail at three social dimensions of humanitarian practice. The first is 'the normative dimensions of humanitarian action'. These are the personal and ethical values that inspire humanitarian activities and the values and principles of the people who are the recipients of these policies. The values of recipients and practitioners can be in harmony, but they can also be incompatible, and where this is the case, there may be a need to negotiate around these differences. Meertens (20I0) illustrates this point using the example of displaced women in Columbia and the tensions between their personal values and the values embodied in policies and services.

Hilhorst, Dijkzeul, and Herman (20I0) call the second dimension 'everyday practice'. These are features of the immediate social context and include the role played by local actors and the organisational structure of humanitarian and local organisations. The interplay between these features and humanitarian activities can influence the effectiveness of policies and services. Richards (20I0) illustrates the first 
aspect of everyday practice, namely the role played by local actors, with an account of local social loyalties in Sierra Leone and the need for humanitarian programmes to work with them rather than against them. In a similar way, Hilhorst and Serrano (2010) demonstrate how aid provision in Angola between 1975 and 2008 was not delivered solely by external international humanitarian agencies but by complex negotiations between international humanitarians and multiple local agencies and groups. Given the important contribution that local actors make, humanitarian agencies have a clear interest in building local capacity so that local people can contribute effectively and take charge of the development process. This is problematic for international non-governmental organisations (NGOs), however, given their focus on immediate emergency response rather than long-term development planning (Christoplos, 2005). As a result, local capacity-building tends to be tacked on to the humanitarian agenda and typically involves training workshops rather than necessary structural interventions (Christoplos, 2005).

The humanitarian sector reflects regularly on the second aspect of everyday practice, namely organisational structure and its influence on the effectiveness of policy (Weiss and Hoffman, 2007). Clarke and Ramalingham (2008), for instance, apply Handy's (I999) typology of organisational structures to humanitarian contexts. This typology includes 'The Club Culture', where the organisation is an extension of the personality of the director, and 'The Role Culture', which takes the form of a pyramid of hierarchically and logically structured job roles. The former tends to be informal and can be responsive, effective, and creative, but it is highly dependent on the individual personalities who make up the team and it is easy for these personal relationships to break down (Handy, I999). The latter tends to be stable and consistent but is less able to respond to new circumstances with speed, independence, and initiative. Differences in organisational structure like these may have an important bearing on the success or failure of humanitarian action (DuBrin, I997).

The third and final social dimension of humanitarian action identified by Hilhorst, Dijkzeul, and Herman (20I0) is the impact of long-term humanitarian intervention on the wider structure of recipient societies. Büscher and Vlassenroost (2010), for example, describe the consequences of the continued international humanitarian presence in the city of Goma, Democratic Republic of the Congo. They show how this has unwittingly encouraged state withdrawal from urban planning and public service provision, and how this is leading to deregulated urban development that favours some social groups over others.

\section{Social dimensions of scientific practice}

It is well documented in the social study of science literature that similar social dimensions are at play when the scientific community advises policy and the wider public (Forsyth, 2003; Irwin and Michael, 2003; Yearley, 2005). While there are many factors that influence whether scientific research has a demonstrable impact beyond the academic world (Collingridge and Reeve, I986; Rier, 2003), the motivations and 
values of individual scientists can effect which science is developed for policy (Lackey, 2007; Johnston, 2009). For instance, research has been conducted on the personal values that motivate scientists to disseminate their research findings to policymakers and communities (Rier, 2003; Jindal-Snape and Snape, 2006). Martin-Sempere, Garzon-Garcia, and Rey-Rocha (2008) found that scientists at the Madrid Science Fair in Spain had diverse reasons for communicating their science to the wider public, including strong altruistic motivations and a sense of duty. Friendships and other personal experiences also may stimulate scientists' involvement in the policy process (Dickens, I996).

Everyday practice effects the application of natural science to policy in a variety of ways, such as the active role of community in the co-production of knowledge, the role of informal lay-person networks in facilitating the science-led policy process, and differences between stakeholders in the type of knowledge they produce and the methods they use to do so (Yearley, 2005). There is a growing consensus that science's role in policy should be as part of a process of knowledge co-production between expert and lay communities (Jasanoff, 2004). This is a two-way dynamic in which lay community understanding of the particular contexts in which policy is delivered is included in the decision-making process. In this sense lay people are the local knowledge experts (Fischer, 2005). Experts are not formal advisers but educators, facilitators, and partners in a wider interpretative community (Kinsella, 2002). There are many examples of local communities actively co-producing scientific knowledge and influencing the policy process (Wynne, I996; Mercer et al., 20I0). Epstein (2000), for instance, has documented the important influence that the lesbian and gay communities in the United States had on the development of clinical trials and treatments for acquired immune deficiency syndrome (AIDS). Many of these activists were professionals in other fields and quickly acquired the necessary scientific expertise to mobilise and advance their cause (Epstein, 2000). Local indigenous communities, for example, that have experienced repeated hazard events can accumulate useful, if not strictly scientific, knowledge and coping strategies, and elements of these may be incorporated effectively in DRR initiatives (Cronin et al., 2004). Lay actors can play an important part in the co-production of science and science-led policy but need the capacity to engage meaningfully with scientific knowledge, concepts, and methods (HFP, 2007). This can be problematic for humanitarian organisations where the longer-term investment and commitment needed to develop scientific skills and learning within humanitarian institutions and local partners runs counter to policy planning time frames and funding mechanisms designed to respond to immediate need (HFP, 2007).

A second impact of everyday practice relates to the informal structure of many lay organisations. This informality can be a source of innovation and energy but also may mean that they are unsustainable in the longer term (Pelling et al., 2008). One characteristic of communities that have worked successfully with scientists to address local problems is that they are able to draw on pre-existing contacts with people of influence (such as local politicians and media representatives), and they can mobilise 
these actors in a way that supports their activities. Brown and Mikkelsen (I997) illustrate this in their study of the community response to toxic waste contamination in Woburn, Massachusetts. In this instance, informal contact with academics at the Harvard School of Public Health and with lawyers greatly helped the community to make their case to politicians and industry. Loose and fluid networks of this sort function because of personal trust among members and unspoken goals and values; their strength is their flexibility and ability to generate new ways of doing things (Pelling et al., 2008). However, they tend to be less ordered and not as longlasting as more formal organisations. For Griffin, Shaw, and Stacey (I999), the ideal arrangement involves a mixture of formal and informal elements that enable creativity and flexibility to sit within a context of continuity and stability.

A third aspect of everyday practice relates to the ways in which groups engaged in science-led policy co-production differ in the type of knowledge they produce and the methods they use to do so (Wynne, I996). These differences can lead to tensions and misunderstandings that may need to be negotiated. For example, scientific knowledge is abstract and consists of general principles confirmed by the scientific community over a long period of time, while lay knowledge is concrete, and is obtained through direct personal experience (Fischer, 2005). Differences of this sort can be the source of dispute. Wynne (I996), for instance, describes how after radiation from the Chernobyl (Ukraine) nuclear power station fell on the Cumbrian fells (United Kingdom) in I986, government scientists conducted experiments to identify ways to reduce sheep contamination, which brought them into conflict with local hill farmers. Wynne (1996) describes one experiment with Bentonite (a sticky clay) that established research had demonstrated to have useful absorbent properties and which scientists thought could be used to soak up the contaminating radiation. A number of sheep pens were built on uniformly contaminated grazing on which differing amounts of Bentonite had been spread, and measurements were taken to see if sheep were less contaminated in the pens with high concentrations of absorbent Bentonite. The farmers were sceptical because in their experience, unnaturally confining hill sheep in this way caused the health of the sheep to deteriorate quickly, and this they thought would undermine the validity of the experiment. The experiment did not work and was abandoned after a few months, although the validity of the farmer's view was never acknowledged (Wynne, I996). This was a conflict between expert and lay knowledge. The scientist's starting point had been existing scientific opinion on the properties of Bentonite, whereas the farmer's had been their personal, practical knowledge of the behaviour of their sheep. Wynne (I996) describes how a series of misunderstandings and differences of this sort ultimately undermined cooperation and trust between the farmers and Ministry of Agriculture, Forestry and Fisheries (MAFF) scientists and impacted on the effective application of science to policy.

The third and last of the social dimensions of humanitarian practice identified by Hilhorst, Dijkzeul, and Herman (20IO) is the effect of long-term humanitarian presence on the wider structure of society; similar arguments are made with regard to science. The scientific method stresses systematic observation and measurement and 
a commitment to ensuring theories and hypotheses are open to testing and falsification (Yearley, 2005). As such, science's emphasis on scepticism, empirical truth, and materialism may run counter to the values and world view of some societies (Cronin et al., 2004). The growing literature on indigenous understanding of natural hazards contains many examples of where the differences between scientific and traditional understandings of hazards have had to be negotiated carefully before long-term effective DRR strategies could be developed and implemented (Mercer et al., 20IO).

Other longer-term impacts of science-led policy on societies relate to the form taken by these interventions. Science plays an important part in advising and guiding the activities of politicians and policymakers, yet the relationship between science and the wider public often is understood to take the shape of a simple deficit model (Irwin and Michael, 2003; Yearley, 2005). This is the view that the public's lack of scientific understanding is a contributing factor in many social problems and is best addressed through education and science communication programmes (Irwin and Michael, 2003). Science communication and education programmes are important, of course, but as the critical paradigm within hazards research shows, community vulnerability is caused by the unequal distribution of resources and political power within societies, frequently along class, gender, and ethno-religious lines (Pelling, 200I; Wisner et al., 2004). While better science education and communication may be part of the solution to particular problems, on their own they may not be enough, and attention must also be paid to the underlying social structures that cause vulnerability (Elder et al., 2007).

It is also important to acknowledge the complex 'triple helix' of university, state, and industry and its influence on the extent and the ways in which scientists engage with user communities (Etzkowitz and Leydesdorff, I997). Most scientific research is funded by government, non-government, and corporate agencies, and this has a bearing on the way in which university science is conducted (Demeritt, 2000). For example, there is mounting pressure on universities to facilitate government decision-making by carrying out policy-relevant research, and government research funds are distributed using competitive market-based mechanisms (Demeritt, 2000). Consequently, the need to demonstrate research impact and attract external funding has become a major factor influencing the work of scientists, but, paradoxically, fuller user-community engagement is discouraged because exchange activities often do not easily translate into the publishable research outputs counted in academic reward structures (Wilby, 20I0). Effective exchange activities are dependent on skilled people acting as brokers between communities, but brokering remains low on the list of funding council priorities (Wenger, 2000). Individual scientists may have to engage with user groups 'in their own time' because knowledge exchange is not funded through their formal researcher context (Wilby, 20Io).

As this section has shown, the social dimensions that underpin the role of natural science in the policy process are broadly comparable to those that influence humanitarian action. Despite these similarities, to date no one has brought these areas 
together to consider instances where natural scientists are directly supporting humanitarian activities and the part that underlying social dimensions play in this process. The remainder of this paper addresses this gap using the findings of qualitative research conducted in the city of Padang, Sumatra, Indonesia. This case study considers the interaction between individual geoscientists and a local NGO, KOGAMI (Komunitas Siaga Tsunami/Tsunami Alert Community), in the development of earthquake and tsunami DRR. It focuses in particular on the first two social dimensions that Hilhorst, Dijkzeul, and Herman (20I0) identify, namely personal and ethical values and everyday practice, and it shows how these hindered but also enabled the DRR process.

\section{Case study: earthquake and tsunami hazard and DRR in Padang, Sumatra}

Indonesia is one of the world's most seismically active countries (McCue, I999). In recent years the principal source of its largest and most devastating earthquakes has been the Sunda megathrust (see Figure I). Here the Indo-Australian plate is being subducted beneath the Eurasian plate. West of Sumatra the megathrust has produced destructive tsunamigenic earthquakes and will do so again in the future (Natawidjaja et al., 2006). The megathrust ruptured and generated the devastating Indian Ocean tsunami on 26 December 2004, killing more than 225,000 people (Stein and Okal, 2005; Huppert and Sparks, 2006). The highest concentration of deaths occurred in the northern Sumatran province of Aceh where a series of waves of up to 30 metres in height inundated the coastline within 30 minutes of the earthquake. Since this event, a sequence of large earthquakes has broken the megathrust between Simeulue Island and the Sunda Strait. The largest of these occurred on 28 March 2005, when a magnitude 8.7 earthquake ruptured the megathrust beneath the islands of Simeulue and Nias (Nalbant et al., 2005) and claimed the lives of approximately I,ooo people (Beetham and Sinclair, 2008). In 2007, a series of three large earthquakes shook the city of Bengkulu and generated a small tsunami; again the tsunami took about 30 minutes to reach the Sumatran coast (Red Cross, 2007; Konca et al., 2008). In 2009, the city of Padang on the western coast of Sumatra was shaken by a magnitude 7.6 earthquake, which demolished buildings throughout the city and generated landslides in coastal mountains, and killed more than I,ooo people (Sudaryo et al., 20I2). The 2009 event did not occur on the megathrust but ruptured a fault some 80 kilometres beneath the surface. Consequently, it did not significantly relax the 200 years of accumulated stress on the Mentawai segment of the Sunda megathrust and hence the potential for a future great (magnitude of more than 8.5) earthquake off the Sumatran coast remains high (McCloskey et al., 20I0). Such an event has the potential to cause significant loss of life in major population centres lying broadside to this section of the trench, including the city of Padang (McCloskey et al., 2008).

Padang is the provincial capital of West Sumatra and is home to almost one million people. Current population densities in the city are especially high in low-lying areas 
Figure 1. Padang and source, setting, and magnitude of recent destructive earthquakes on the Sunda Megathrust

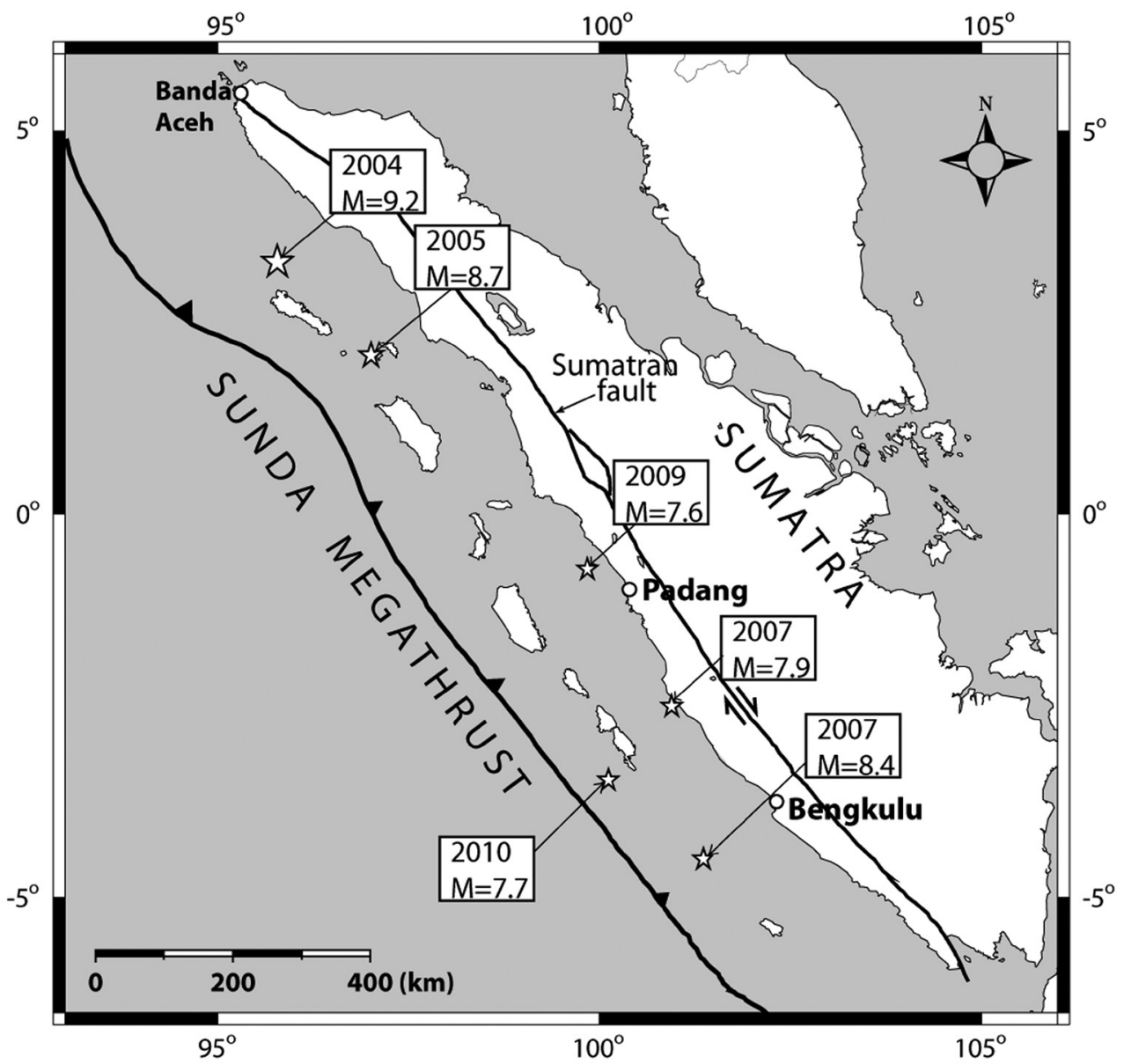

Source: author.

within two kilometres of the coastline (Taubenböck et al., 2008). In the event of a future Mentawai tsunamigenic earthquake it is likely that these areas will be devastated through ground shaking and inundation, and loss of life will be significant without the implementation of effective mitigation and preparedness activities (Taubenböck et al., 2008; McCloskey et al., 2008, 2010).

The Muslim Minangkabau are Padang's dominant ethnic group, and practice a form of Islam mixed with Adat (local customs, beliefs, and practices from pre-colonial Minangkabau society) (Blackwood, 200I; Cohen, 2003). Indonesians of Chinese decent are the largest minority population in Padang (Colombijn, I996; Suryadinata, Arifin, and Ananta, 2003), and are part of, but also to some extent separate from, 'mainstream' Indonesian society (Ong, 2006). They are recognised as Indonesian citizens (albeit as 'citizens of foreign decent') and most speak local Indonesian languages rather than Chinese (Tan, 200I), but are predominantly Christian (Heidhues, 
I974; Freedman, 2000; Tan, 200I; Hoon, 2006) and live in Chinese neighbourhoods (Suryadinata, Arifin, and Ananta, 2003).

DRR for earthquake and tsunami hazards in Padang prior to the destructive Sunda megathrust earthquakes of 2004 and 2005 was largely non-existent. Subsequently, a range of local, national, and international agencies have become involved in disaster mitigation and preparedness activities. An agreement was signed between the Governments of Germany and Indonesia in March 2005 on developing the GermanIndonesian Tsunami Early Warning System (GITEWS), in which Padang is one of three pilot locations (Spahn et al., 20IO). Mercy Corps developed its first DRR programme in West Sumatra in 2007 and SurfAid has operated health-based programmes in the Mentawai and Nias Island chain for the past Io years, and these have increasingly included DRR elements. In 2008, the Indonesian government established a national disaster management body, BNPB (Badan Nasional Penanggulangan Bencana/ National Disaster Management Agency), and local disaster management agencies, BPBDs (Badan Penanggulangan Bencana Daerah/Regional Disaster Management Agency). BPBDs are now in operation for both Padang and the province of West Sumatra, while others currently are being rolled out across Indonesia.

KOGAMI (The Tsunami Alert Community) is a locally-run NGO based in Padang, and founded in July 2005 . It receives funding from international donors, including Trócaire and the United Nations Educational, Scientific and Cultural Organization (UNESCO), and delivers DRR programmes to schools and communities that explain the causes of tsunamigenic earthquakes and what to do in a tsunami-related emergency. It provided a community education component for GITEWS (GTZ, 2008; Spahn et al., 2010), and partners Mercy Corps in some DRR initiatives. Since 2005 , KOGAMI has been in regular contact with a loose network of international geoscientists (the Geoscience-KOGAMI partnership) engaged in earth science research on the Sunda megathrust. These scientists are employed by various universities and research institutes in Australia, Germany, the UK, and the US, and while they may know each other through their shared research interests (and some have engaged in collaborative research), it is a flexible network of individuals rather than a formal arrangement. Their collaboration with KOGAMI is similarly informal and was initiated by KOGAMI's executive director first by email and later during face-to-face encounters, and it has been sustained via these means.

Interview-based research on the Geoscience-KOGAMI partnership was conducted in Padang over a four-week period from April and May 20IO. Twenty in-depth interviews were held with a variety of DRR practitioners in Padang, and four with KOGAMI employees. In addition, three disaster awareness and preparedness focus groups were convened with members of the local community in Padang, and researchers participated in a number of community education activities. All interviews were facilitated by a translator. Two further interviews with KOGAMI's executive director took place following workshops and meetings in the UK in September 2010 and six formal interviews with participating geoscientists were held from September 20 IO to March 201 I. 
Other collaborations between scientists, government, and NGOs were ongoing in Padang at the time of this research; the study was not intended to be a survey of all of these activities. Instead, as with all case study research, the aim was to gain some detailed insight into a particular example or instance (May and Perry, 20II). It may be that the knowledge and understanding gained are relevant to other contexts, but further research is needed before findings can be generalised with any confidence (Williams, 2002). Nevertheless, there is sufficient good quality data on the workings of the Geoscience-KOGAMI partnership to illustrate various social dimensions of science's role in DRR in the examples reviewed.

\section{Social dimensions of science-humanitarian collaboration on DRR}

This section describes various social dimensions of the Geoscience-KOGAMI partnership, notably: the personal motivations of scientists and NGO workers; evidence of the co-production process; the challenges of integrating lay and expert perspectives; and informal organisational structures and the issue of partnership sustainability.

It was clear that personal ethical motivations of participants were important in both initiating and sustaining the Geoscience-KOGAMI partnership. For example, KOGAMI's executive director's reasons for creating the NGO were rooted in her experience of the Aceh tsunami of 2004:

We saw the big trauma from the television, the horrible tsunami news. This situation make some people want to do volunteering . . . we were volunteering for tsunami victims in some islands, we delivered first aid to the island. Then in 2005 we had a big earthquake in Padang and people didn't know what to do so we decided to make our own NGO as we did not want the tragedy in Aceh to be happening in Padang City (London Workshop, I September 20I0).

Individual geoscientists had similar reasons for participating. One noted that the earthquake and tsunami of 26 December 2004 was also the motivation for his involvement. He felt that earthquake science was 'coming of age' and was now sufficiently precise to allow for the focusing of resources to prepare for high probability, low frequency events. He added that scientists 'must do better' in acknowledging and negotiating the challenges that surround the deployment of their forecasts (London Workshop, I September 20I0).

There was good evidence of KOGAMI's active role in the partnership and the merging of expert and lay perspectives (Kinsella, 2002). KOGAMI had initiated the partnership in order to be taken more seriously by government and other agencies. As the executive director put it:

In the beginning nobody trust us . . we were just volunteers and had no knowledge of earthquake and tsunami. We tried to convince the government and they asked us how you know tsunami would happen in Padang and we had no answer (Interview, 7 September 20IO). 
She also pointed out that it was 'only when we brought the scientists with us did teachers in the schools believe us' (Interview, 26 April 20I0).

KOGAMI staff had some background in science, including degrees in biology, engineering, and medicine, and actively judged the merit of the various sources of expert knowledge available to them. For example, the quality of local scientific research was questioned because the scientist 'had no data with which to base his decisions on', while other research was trusted because 'he [the scientist] has been conducting research in the area for Io years' (KOGAMI Executive Director, Interview, I5 May 20Io). They also assumed a role in directing the focus of scientific research. In one instance they advised a United Nations University team conducting a vulnerability study in Padang on the data it should collect, and played a similar part in a vulnerability study undertaken by GITEWS. As the executive director explained:

I asked them for specific information at sub-village level. KOGAMI found the information very useful as [we] could base target areas on that data. It also helped to develop strategies and plan resources (Interview, I5 May 2012).

There were a number of examples of initiatives that combined expert knowledge with local values and traditions (Kinsella, 2002). For instance, published research on tsunami inundation predictions served as the basis for a simple 'traffic-light', colourcoded tsunami hazard evacuation map. The original research was conducted by the German Remote Sensing and Aerospace Centre, the Indonesian Institute of Sciences, and the Alfred Wegener Institute for Polar and Marine Research at the United Nations University (Schlurmann et al., 20I0; Strunz et al., 20I I). It combined sophisticated high-resolution topographic and bathymetric data with probabilistic earthquake ruptures to forecast patterns of tsunami inundation (Schlurmann et al., 20Io; Strunz et al., 20II). The simplified map used this research to depict evacuation routes over a shaded topographic digital elevation model of Padang City, with land elevations (metres above sea level) categorised and colour-coded. The 'traffic-light' colour system employed on the map alerted people to their level of exposure to a tsunami hazard, with land lower than 5 metres (red) defined as dangerous, land between 5 and Io metres relatively safe, but be alert (yellow), and land above Io metres safe (green and blue). These maps were mounted on billboards and positioned along the city's coastal road and at busy city centre road junctions and formed the basis of community education activities and school-based training programmes. There were also examples of where expert input was mixed with traditional beliefs to create useful hybrid forms (Shannon, Hope, and McCloskey, 20II). For instance, KOGAMI ran a tsunami awareness programme in a number of fishing villages with the help of elders who were thought by locals to have the ability to predict storms (tuo pantai). DRR workers used a hardboiled egg with a cracked shell to explain that earthquakes are caused when the shell breaks apart, how earthquakes happen along the cracks in the shell, and how Padang is at risk because it is near one of these cracks. The esteem accorded to tuo pantai by local people helped to ensure that the advice was taken seriously. 
There was also evidence of tensions between lay and expert knowledge of the type that Wynne (I996) described. KOGAMI's emphasis on immediate humanitarian response and the longer time frames needed to produce the earthquake science was a source of frustration (HFP, 2007). This became apparent when it took three years for geoscientists and various GITEWS partners to produce an updated secondgeneration tsunami hazard map. One NGO representatives noted:

We depend on what's already been done and use resources that are already available. We don't have time to wait for scientists to write a proposal and get funding. We need to get moving straight away so if it's a choice between using older information and the most up-to-date stuff, we will use what is most accessible (Interview, Mercy Corps Representative, 27 April 20IO).

For KOGAMI and other NGOs, these delays happened because scientists were reluctant to share their data with other scientists. The concern of the scientists was that map quality would be compromised if research was rushed.

Disagreement among scientists was quite common in the stakeholder meetings that informed the production of the second-generation map. For the scientists, robust debate was an important mechanism to ensure the quality of the science. For some local NGOs, however, these debates gave the impression of a scientific community detached from the practical implications of their work. One DRR adviser pointed out:

My organisation does not need to know the specifics, we just need the basics . . the problem with scientists is that they never agree . . . they were just showing off (Interview, SurfAid representative, 6 May 2010).

It was also clear that the DRR co-production process was quite heavily reliant on informal relationships between KOGAMI and the wider community in Padang. For example, the executive director noted:

When we first started [DRR canvassing] we have one person who is a friend of my uncle, he knows the chief of the fire department and the chief of the fire department has good links to everybody in the government . . . the person with good links never has a problem. He helped us a lot (Interview, 7 September 20IO).

In a similar way, the executive director credited the success of KOGAMI's first tsunami evacuation drill in Padang to assistance from the army and the police department, which provided the cars and staff necessary to mobilise and facilitate the event. They were able to gain this support because the executive director 'was friends with a police officer and was [therefore] in a position to ask him for staff and cars ... it is through my family that I know him' and they were able 'to get through to the army through a friend' (Interview, Io May 2010).

Informal personal interaction between partnership members also played an important role. These were mainly email exchanges and occasional face-to-face meetings 
at conferences and workshops, in Indonesia, Europe, and the US. In some cases these contacts had developed into friendships that helped to ensure effective and prompt communication. While this structure delivered some of the strengths of informal organisations (creativity, responsiveness), it also raised questions about the capacity of the present arrangement and its sustainability in the longer term. Like Handy's (I999) 'Club Culture', it was heavily dependent on a small number of key people and the good personal relationships between them, rather than a formal arrangement that would guarantee continuity even when the individuals in those roles move on. These points were not lost on KOGAMI's executive director who had concerns about her organisation's ability to sustain its role in the partnership as 'local expert'. For instance, she highlighted that 'we need specialist disaster management training . . . but there are no courses in Sumatra and we don't have the money to do it on our own' (Interview, Iо May 20I0). The geoscientists also acknowledged the ad hoc nature of the arrangement. One observed that 'it is difficult for us to sustain this level of engagement without a permanent funding . . . I don't want to do it all myself . . . I need to get back to the science which is the bit I'm good at and for there to be a team of people who are good at the community engagement part' (Interview, 23 June 20I0).

\section{Conclusion}

For Anderson (I999), humanitarians must be mindful of the social dimensions of their practice, and how these interact with existing sources of good and harm in local settings. As science-humanitarian partnering becomes more common it is important to include science in these considerations. This paper has contributed to this endeavour by identifying common themes in the social study of science and the social dimensions of humanitarian practice literature, and by exploring their relevance in the KOGAMI-Geoscience partnership in Padang, Sumatra. The findings draw particular attention to knowledge co-production processes, and to the informality of the KOGAMI-Geoscience partnership and the challenge of building capacity to sustain and develop its activities in the future.

From this analysis one can make three conclusions. First, the analysis draws attention to the challenge of moving beyond traditional models of humanitarian capacitybuilding. In the traditional approach, international partners take the leadership role, local partners do service delivery, and capacity-building is dominated by the 'training fix' where local stakeholders learn 'about' policy development but do not do it (Christoplos, 2005). Genuine knowledge co-production requires a more fundamental two-way transformation of the roles of science and humanitarian partnership elements: the former as educator and enabler rather than as expert adviser, and the latter informing and at times leading the co-production process in the light of local expert knowledge (Kinsella, 2002). Further investment in ongoing research council efforts to reward boundary work (see, for example, RCUK, 2009), is needed to enhance science's ability to recognise and respond to humanitarian needs. Considerable financial 
commitment is required to create genuinely robust local structures to engage in knowledge co-production and to develop science capacity in local civil societies and beyond (Christoplos, 2005).

Second, the analysis throws into relief the specific social and organisational arrangements that underpin the Geoscience-KOGAMI relationship and that need to be in place if there is to be effective exchange of knowledge between scientists and local DRR practitioners. The distinction between formal and informal organisations is made frequently (Pelling et al., 2008) and the Geoscience-KOGAMI case is situated towards the informal end of this spectrum. Formal organisations are characterised as stable and regulated by explicit guidelines and standardised management processes, whereas informal organisations are loose and fluid networks that function because of personal trust between members and unspoken goals and values. Both types of organisation have strengths and weaknesses. Formal organisations tend to be lasting and well-ordered but lack creativity and responsiveness, whereas informal organisations are flexible and generate new ways of doing things but tend towards instability and randomness (Griffin, Shaw, and Stacey, I999). In our view, the GeoscienceKOGAMI partnership exhibits both the positive and negative features of informal organisations. The personal contacts that were a feature of the arrangement meant that requests for information and help could be generous and swift, and the open and loose network created space for community-level organisations to play an active part in creating useful and effective hybrid DRR measures. On the negative side, the personalised nature of the network meant that there was a danger of over-reliance on particular individuals and the break-up of the partnership if they were to move on. For Griffin, Shaw, and Stacey (1999), the ideal arrangement contains a mixture of formal and informal elements that enable creativity and flexibility to sit within a context of continuity and stability; in our opinion, this is a key challenge for the Geoscience-KOGAMI partnership. Future research might explore how the inherent weaknesses of its informal structure can be addressed without compromising the vibrancy and flexibility of the arrangement.

Third, while the longer-term impacts of science-humanitarian partnering were not explored in the case study, the analysis raises some issues and highlights possible avenues for future research, regarding the longer-term effects of these partnerships. Arguably, KOGAMI-Geoscience programmes follow the deficit model as they aim to enhance community awareness of the natural processes that cause earthquake and tsunami hazard and advise on what to do in an emergency (Irwin and Michael, 2003; Yearley, 2005). Further research is needed to consider the extent to which these policies address and have a lasting impact on the social causes of vulnerability in Padang and whether different social groups (such as the minority Indonesian Chinese) have equal access to DRR support of this type. It may be that one of the long-term ramifications of science-humanitarian partnering is that strategies that tackle the social causes of natural hazards vulnerability are neglected because the dialogue is dominated by natural science perspectives and methodologies (Forsyth, 2003).

Finally, it is clear that underlying social dimensions will continue to influence the success or otherwise of the KOGAMI-Geoscience partnership. This makes it essential 
to develop theoretical frameworks of the social dimensions type, in order to identify, analyse, and address these processes so that science-humanitarian collaboration is enhanced and community vulnerability reduced. This approach may have wider utility as its principles and concepts are relevant to any situation where there is sharing of knowledge, expertise, and best practice. It may be transferable, for instance, to other types of humanitarian partnership-building, including the sharing of complementary expertise between NGOs, inter-agency collaboration with donors and national actors, and corporate-humanitarian partnering. Further research on the social dimensions of humanitarian collaboration, to address these issues at a range of geographic scales and in different partnership types, is required.

\section{Correspondence}

Dr Rachel Shannon, Environmental Sciences Research Institute, School of Environmental Sciences, University of Ulster, Cromore Road, Coleraine, BT52 ISA, Northern Ireland. E-mail: rachelshannon4Io@hotmail.com

\section{Endnotes}

I Rachel Shannon is Research Officer at the National Children's Bureau, Northern Ireland; Max Hope is Lecturer in Geography at the School of Environmental Sciences, University of Ulster, Coleraine, United Kingdom; John McCloskey is Professor of Geophysics at the School of Environmental Sciences, University of Ulster, Coleraine, United Kingdom; Dominic Crowley is Head of Emergency Unit at Concern Worldwide, Lower Dublin, Ireland; and Peter Crichton is Emergency Preparedness Coordinator at Concern Worldwide, Lower Dublin, Ireland.

\section{References}

Anderson, M.B. (1999) Do No Harm: How Aid Can Support Peace-Or War. Lynne Rienner Publishers, London.

Beetham, D. and B. Sinclair (2008) 'Uplift and damage from the $\mathrm{M}_{\mathrm{w}} 8.7$ Nias earthquake of 28 March 2005'. Resilient Organisations Research Report. 2. http://www.irbnet.de/daten/iconda/CIBII504.pdf (accessed on 25 February 2010).

Blackwood, E. (200I) 'Representing women: the politics of Minangkabau Adat writings'. The Journal of Asian Studies. 60(I). pp. I25-I49.

Brown, P. and E.J. Mikkelsen (1997) No Safe Place: Toxic Waste, Leukemia and Community Action. University of California Press, Berkeley, CA.

Budds, J. (2009) 'Contested $\mathrm{H}_{2} \mathrm{O}$ : science, policy and politics in water resources management in Chile'. Geoforum. 40(3). pp. 4I8-430.

Büscher, K. and K. Vlassenroot (20I0) 'Humanitarian presence and urban development: new opportunities and contrasts in Goma, DRC'. Disasters. 34(2). pp. 256-273.

Christoplos, I. (2005) 'Institutional capacity building amid humanitarian action'. ALNAP Review of Humanitarian Action in 2004: Active Learning Network for Accountability and Performance in Humanitarian Action Research Report. http://www.alnap.org/resource/5215.aspx (accessed on 29 April 20I4). 
Clarke, P. and B. Ramalingam (2008) 'Organisational change in the humanitarian sector'. ALNAP Review of Humanitarian Action: Active Learning Network for Accountability and Performance in Humanitarian Action Research Report. http://www.alnap.org/resource/523I.aspx (accessed on 29 April 2014).

Cohen, M.I. (2003) 'Look at the clouds: migration and West Sumatran popular theatre'. New Theatre Quarterly. I9(3). pp. 214-229.

Collingridge, D. and C. Reeve (1986) Science Speaks Truth to Power: The Role of Experts in Policymaking. St. Martin's Press, New York, NY.

Colombijn, F. (1996) 'City profile: Padang'. Cities. I3(4). pp. $28 \mathrm{I}-288$.

Cronin, S.J., M.J. Petterson, M.W. Taylor, and R. Biliki (2004) 'Maximising multi-stakeholder participation in government and community volcanic hazard management programs; a case study from Savo, Solomon Islands'. Natural Hazards. 33. pp I05-I36.

Demeritt, D. (2000) 'The new social contract for science: accountability, relevance and value in US and UK science and research policy'. Antipode. 32 (3). pp. 308-329.

Dickens, P. (1996) Reconstructing Nature: Alienation, Emancipation and the Division of Labour. Routledge, London.

DuBrin, A.J. (1997) Fundamentals of Organizational Behaviour: An Applied Approach. South-Western College Publishing, Cincinnati, $\mathrm{OH}$.

Elder, K. et al. (2007) 'African Americans decisions not to evacuate New Orleans before Hurricane Katrina'. American Journal of Public Health. 97(I). pp. I24-I29.

Epstein, S. (2000) 'Democracy, expertise, and AIDS treatment activism'. In D.L. Kleinman (ed.) Science, Technology and Democracy. State University of New York Press, Albany, NY. pp. I5-32.

Etzkowitz, H. and L. Leydesdorff (I997) 'Introduction to special issue on science policy dimensions of the triple helix of university-industry-government relations'. Science and Public Policy. 24(2). pp. 2-5.

Fischer, F. (2005) Citizens, Experts and Environment: The Politics of Local Knowledge. Duke University Press, Durham, NC.

Forsyth, T. (2003) Critical Political Ecology: The Politics of Environmental Science. Routledge, London.

Freedman, A.L. (2000) Political Participation and Ethnic Minorities: Chinese Overseas in Malaysia, Indonesia and the United State. Routledge, New York, NY.

Gergen, K.J. (1985) 'The social constructionist movement in modern psychology'. American Psychologist. $40(3)$. pp. 266-275.

Griffin, D., P. Shaw, and R. Stacey (1999) 'Knowing and acting in conditions of uncertainty: a complexity perspective'. Systemic Practice and Action Research. I2 (3). pp. 295-309.

GTZ (Deutsche Gesellschaft für Internationale Zusammenarbeit) (2008) Capacity Building in Local Communities: German-Indonesian Cooperation for Tsunami Early Warning System. Newsletter. 8 (OctoberDecember). http://www.gitews.org/index.php?id=35\&L=I (accessed on I 4 June 20IO).

Handler Chayes, A., A. Chayes, and G. Raach (I997) 'Beyond reform: restructuring for more effective conflict intervention'. Global Governance. 3(2). pp. II7-I 45 .

Handy, C. (1999) Understanding Organizations. Penguin, London.

Heidhues, M.F. (1974) Southeast Asia's Chinese Minorities. Longman, Melbourne.

HFP (Humanitarian Futures Programme) (2007) Promoting the Dialogue between Scientists and Humanitarians. Humanitarian Futures Briefing Paper. September. http://www.humanitarianfutures.org/ publications/briefing-paper-promoting-dialogue-between-scientists-and-humanitarians/ (accessed on 29 April 20I4).

Hilhorst, D. and M. Serrano (2010) 'The humanitarian arena in Angola 1975-2008'. Disasters. 34(2). pp. I $83-20$.

Hilhorst, D., D. Dijkzeul, and J. Herman (2010) 'Editorial: social dynamics of humanitarian action'. Disasters. 34(2). pp. I27-I29.

Hoon, C-Y. (2006) Reconceptualising Ethnic Chinese Identity in Post-Suharto Indonesia. PhD dissertation. University of Western Australia, Crawley, WA. 
Huppert, H.E. and S. Sparks (2006) 'Extreme natural hazards: population growth, globalisation and environmental change'. Philosophical Transactions of the Royal Society. 364(I845). pp. I875-I888.

Irwin, A. and M. Michael (2003) Science, Social Theory and Public Knowledge. Open University Press, Maidenhead.

Jasanoff, S. (2004) 'The idiom of co-production'. In S. Jasanoff (ed.) States of Knowledge: The Coproduction of Science and Social Order. Routledge, London. pp. I-I3.

Jindal-Snape, D. and J.B. Snape (2006) 'Motivation of scientists in a government research institute: scientists' perceptions and the role of management' Management Decision. 44(IO). pp. I325-I343.

Johnston, A.T. (2009) 'When scientists get involved in public policy' Biomedical Engineering Society Newsletter. $33(3)$. pp. I, 4 .

Kennedy, D. (2008) The Dark Side of Virtue: Reassessing International Humanitarianism. Princeton University Press, Princeton, NJ.

Kinsella, W.J. (2002) 'Problematizing the distinction between expert and lay knowledge'. New Jersey Journal of Communication. IO(2). pp. I9I-207.

Konca, A.O. et al. (2008) 'Partial rupture of a locked patch of the Sumatra megathrust during the 2007 earthquake sequence'. Nature. 456. pp. 63I-635.

Lackey, R.T. (2007) 'Science, scientists, and policy advocacy'. Conservation Biology. 2I(I). pp. I2-I7.

McCloskey, J. et al. (2008) 'Tsunami threat in the Indian Ocean from a future megathrust earthquake west of Sumatra'. Earth and Planetary Science Letters. 265. pp. 6I-8I.

McCloskey, J. et al. (2010) 'The September 2009 Padang earthquake'. Nature Geoscience. 3. pp. 70-7I.

McCue, K. (I999) 'Seismic hazard mapping in Australia, the Southwest Pacific and Southeast Asia'. Annals of Geophysics. $42(6)$. pp. II9I-II98.

Martin-Sempere, M.J., B. Garzon-Garcia, and J. Rey-Rocha (2008) 'Scientists' motivation to communicate science and technology to the public: surveying participants at the Madrid Science Fair'. Public Understanding of Science. I7(3). pp. 349-367.

May, T. and B. Perry (20I I) 'Case study research'. In T. May (ed.) Social Research: Issues, Methods and Process. Fourth edition. Open University Press, Maidenhead. pp. 219-242.

Meertens, D. (20I0) 'Forced displacement and women's security in Colombia'. Disasters. 34(2). pp. I47-I64.

Mercer, J., I. Kelman, L. Taranis, and S. Suchet-Pearson (20IO) 'Framework for integrating indigenous and scientific knowledge for disaster risk reduction'. Disasters. 34(I). pp. 2I4-239.

Nalbant, S.S., S. Steacy, K. Sieh, D. Natawidjaja, and J, McCloskey (2005) 'Earthquake risk on the Sunda Trench'. Nature. 435(9). pp. 756-757.

Natawidjaja D.H. et al. (2006) 'Source parameters of the great Sumatran megathrust earthquakes of I797 and I 833 inferred from coral microatolls'. Journal of Geophysical Research. I I (B6). doi:I0. I029/2055JBo04025. http://onlinelibrary.wiley.com/doi/I0.1029/2005JBo04025/abstract (accessed on 29 April 20I4).

Ong, A. (2006) Neoliberalism as Exception: Mutations in Citizenship and Sovereignty. Duke University Press, London.

Pelling, M. (200I) 'Natural disasters?'. In N. Castree and B. Braun (eds.) Social Nature: Theory, Practice and Politics. Blackwell Publishers, Oxford. pp. I70-I89.

Pelling, M., C. High, J. Dearing, and D. Smith (2008) 'Shadow spaces for social learning: a relational understanding of adaptive capacity to climate change within organizations'. Environment and Planning $A$. 40(4). pp. 867-884.

Pelling, M. and K. Dill (2010) 'Disaster politics: tipping points for change in the adaption of sociopolitical regimes'. Progress in Human Geography. 43 (I). pp. 2I-37.

RCUK (Research Councils United Kingdom) (2009) Knowledge Transfer Portal. http://www.bbsrc.ac.uk/ news/archive/2009/090225-n-launch-knowledge-transfer-portal.aspx (accessed on II October 20I2).

Red Cross (2007) Indonesia: Bengkulu Earthquake. Information Bulletin. 4. http://www.ifrc.org/docs/ appeals/rptso7/ideq03I007-04.pdf (accessed on I June 2009).

Richards, P. (20I0) 'Ritual dynamics in humanitarian assistance'. Disasters. 34(2). pp. I38-I46. 
Rier, D.A. (2003) 'Work setting, publication, and scientific responsibility'. Science Communication. 24(4). pp. $420-457$.

Schlurmann, T., W. Kongko, N. Goseberg, D.H. Natawidjaja, and K. Sieh (2010) 'Near field tsunami hazard map Padang, West Sumatra: utilizing high resolution geospatial data and reasonable source scenarios'. Proceedings of the International Conference on Coastal Engineering Symposium. http://journals. tdl.org/ICCE/article/viewArticle/I Ioo (accessed on 22 September 20II).

Shannon, R., M. Hope, and J. McCloskey (20II) 'The Bengkulu premonition: cultural pluralism and hybridity in disaster risk reduction'. Area. 43(4). pp. 449-455.

Spahn, H., M. Hoppe, H.D. Vidiarian, and B. Usdianto (20Io) 'Experience from three years of local capacity development for tsunami early warning in Indonesia: challenges, lessons and the way ahead'. Natural Hazards and Earth System Sciences. IO. pp. I4I I-I429.

Stein, S. and E.A. Okal (2005) 'Speed and size of the Sumatra earthquake'. Nature. 434. pp. 58I-582.

Stockton, N. (I998) 'In defence of humanitarianism'. Disasters. 22 (4). Pp. 352-360.

Strunz, G. et al. (20II) 'Tsunami risk assessment in Indonesia'. Natural Hazards and Earth System Sciences. II. pp. $67-82$.

Sudaryo, K. et al. (2012) 'Injury, disability and quality of life after the 2009 earthquake in Padang, Indonesia: a prospective cohort study of adult survivors'. Global Health Action. 5. pp. I-II.

Suryadinata, L., E.N. Arifin, and A. Ananta (2003) Indonesia's Population. Institute of Southeast Asian Studies, Singapore.

Tan, E.K.B. (200I) 'From sojourners to citizens: managing the ethnic Chinese minority in Indonesia and Malaysia'. Ethnic Racial Studies. 24(6). pp. 949-978.

Taubenböck, H. et al. (2008) Multi-scale Assessment of Population Distribution Utilizing Remotely Sensed Data: The Case Study Padang, West Sumatra, Indonesia. International Conference on Tsunami Warning (ICTW), Bali, Indonesia, I2-I4 November 2008.

Weiss, T. and P. Hoffman (2007) 'The fog of humanitarianism: collective action problems and learningchallenged organisations'. Journal of Intervention and Statebuilding. I(I). pp. 47-65.

Wenger, E. (2000) 'Communities of practice and social learning systems'. Organization. 7(2). pp. $225-246$.

Wilby, R.L. (20I0) 'How climate science can effectively inform humanitarian and development planning and programmes - a climate scientist perspective'. Humanitarian Futures Programme. http:// www.humanitarianfutures.org/hfpubs/wilby (accessed on I November 20I2).

Williams, M. (2002) 'Generalization in interpretative research'. In T. May (ed.) Qualitative Research in Action. Sage, London. pp. I25-I43.

Wisner, B., P. Blaikie, T. Cannon, and I. Davis (2004) At Risk: Natural Hazards, People's Vulnerability and Disasters. Second edition. Routledge, London.

Wynne, B. (I996) 'May the sheep safely graze? A reflexive view of the expert-lay knowledge divide'. In S. Lash., S. Bronislaw, and B. Wynne (eds.) Risk, Environment and Modernity: Towards a New Ecology. Sage, London. pp. 44-82.

Wynne, B. (2006) 'Public engagement as a means of restoring public trust in science-hitting the notes but missing the music'. Community Genetics. 9(3). pp. 2 I I-220.

Yearley, S. (2005). Making Sense of Science: Understanding the Social Study of Science. Sage, London. 